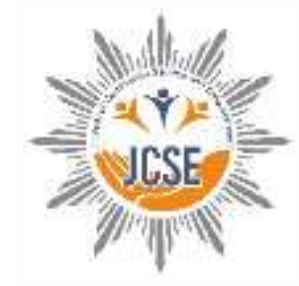

\title{
Journal of Community Service and Empowerment
}

p-ISSN 2722-4244, e-ISSN 2722-5291 // Vol. 1 No. 1 April 2020, pp. 25-30

\section{Training on making cendol starch using blue natural dyes extracted from telang flower essence}

\author{
Muh. Shofi ${ }^{a, 1^{*}}$, Mardiana Prasetyani Putri ${ }^{b, 2}$ \\ ${ }^{a}$ Department of Biology, Institut IImu Kesehatan Bhakti Wiyata Kediri, Indonesia \\ ${ }^{b}$ Department of Chemistry, Institut IImu Kesehatan Bhakti Wiyata Kediri, Indonesia \\ ${ }^{1}$ kirana_shofi@yahoo.com; ${ }^{2}$ neyna_ub@yahoo.co.id \\ * Corresponding author
}



How to cite: Shofi, M., Putri, M.P. (2020). Training on making cendol starch using blue natural dyes extracted from telang flower essence. Journal of Community Service and Empowerment, 1(1), 25-30. doi: https://doi.org/10.22219/jcse.v1i1.11514

\section{PENDAHULUAN}

Bunga telang memiliki nama ilmiah Clitoria ternatea merupakan tanaman yang masuk pada keluarga Fabaceae. Tanaman ini merupakan tanaman merambat dan liar yang banyak ditemukan di pekarangan rumah, tepi hutan, atau pinggiran sawah. Bunga telang bermanfaat sebagai antidiabetes, antiinflamasi, analgesik (Shyamkumar \& Ishwar, 2012), anti-mikroba (Uma et al., 2009), dan mengandung senyawa antosianin dengan aktivitas antioksidan yang tinggi (Vankar \& Srivastava, 2010). Selain itu bunga telang juga dapat dimanfaatkan sebagai zat antikanker. Berdasarkan Ana et al. (2012) bunga telang merupakan salah satu sumber pigmen biru yang belum banyak masyarakat ketahui. Sumber pigmen tersebut berasal dari kandungan antosianian yang banyak tersebar pada tanaman salah satunya bunga yang berwarna ungu.

Desa Datengan merupakan desa yang terletak di Kecamatan Grogol Kabupaten Kediri dengan luas wilayah 2,5 km². Masyarakat Desa Datengan berjumlah 4.436 jiwa yang umumnya bekerja sebagai petani dan wiraswasta (BPS, 2018). Berdasarkan hasil survei lahan persawaan yang ada di desa tersebut banyak ditumbuhi tanaman telang, sehingga perlu adanya suatu pemanfaatan bunga dari tanaman telang sebagai pewarna alami pada makanan salah satunya yaitu pewarna pada pembuatan cendol.

Selama ini, masyarkat desa Datengan masih menggunakan pewarna sintetik guna memberikan warna pada pembuatan cendol pati. Penggunaan pewarna tersebut dapat menyebabkan penyakit bagi tubuh manusia, sehingga perlu 
adanya pengganti pewarna sintetik dengan pewarna alami. Pewarna alami yang dapat digunakan yaitu ekstrak bunga telang yang memiliki warna biru.

Berdasarkan hal tersebut maka perlu diadakan kegiatan edukasi mengenai manfaat dan potensi bunga telang kepada masyarakat Desa Datengan Kecamatan Grogol Kabupaten Kediri agar informasi mengenai manfaat dan potensi bunga telang dapat dipahami secara luas oleh masyarakat. Kegiatan pengabdian kepada masyarakat ini dilakukan bersamaaan dengan kegiatan KKN Institut IImu Kesehatan Bhakti Wiyata Kediri semester genap tahun akademik 2018/2019. Tujuan dari pengabdian ini yaitu meningkatkan pengetahuan masyarakat tentang pemanfaatan bunga telang sebagai pewarna alami pada pembuatan cendol pati pada masyarakat Desa Datengan Kecamatan Grogol Kabupaten Kediri.

\section{METODE}

\section{Waktu pelaksanaan dan lokasi}

Waktu pelaksanaan program ini yaitu pada tanggal 21 Juli - 30 Agustus 2019. Adapun tempat pengabdian di Balai Desa Datengan Kecamatan Grogol Kabupaten Kediri. Peta wilayah Desa Datengan seperti pada Gambar 1.

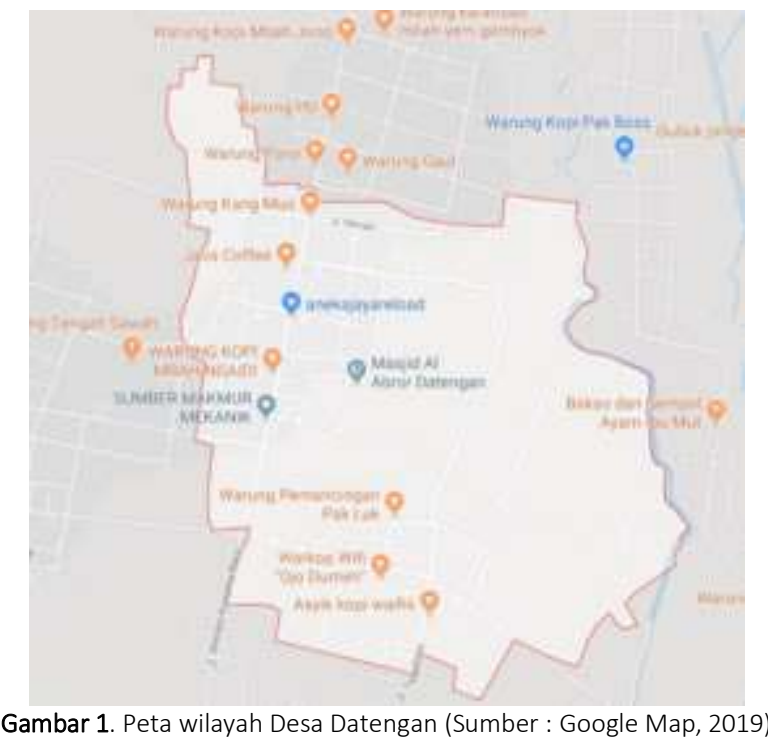

\section{Metode pelaksanaan}

Metode yang digunakan pada pelaksanaan pelatihan pemanfaatan bunga telang (Gambar 2) sebagai pewarna alami pada pembuatan cendol pati seperti pada Tabel 1.

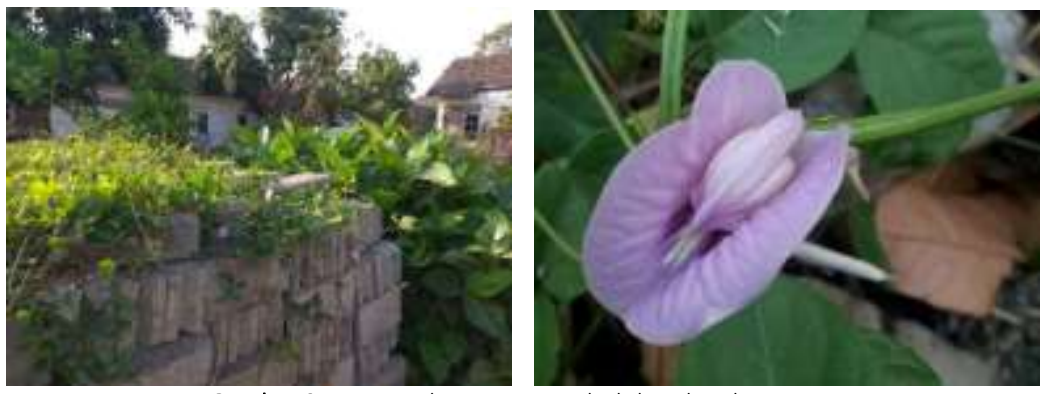

Gambar 2. Bunga telang yang tumbuh liar di pekarangan

Tabel 1. Metode pelaksanaan pengabdian

\begin{tabular}{|c|c|c|c|}
\hline Solusi permasalahan & Jenis Kegiatan & Metode pelaksanaan & Sasaran dan Target \\
\hline $\begin{array}{l}\text { Pemberian informasi kepada } \\
\text { masyarakat mengenai budidaya bunga } \\
\text { telang }\end{array}$ & $\begin{array}{l}\text { Penyuluhan budidaya } \\
\text { bunga telang }\end{array}$ & $\begin{array}{ll}\text { - } & \text { Pembagian Leaflet } \\
\text { - } & \text { Pembagian Kuisioner } \\
\text { - } & \text { Ceramah oleh pakar } \\
\end{array}$ & $\begin{array}{l}\text { Warga Desa Datengan khususnya } \\
\text { Dusun Datengan, dan karang taruna }\end{array}$ \\
\hline Pembuatan pewarna alami warna biru & $\begin{array}{l}\text { Workshop olahan bunga } \\
\text { telang }\end{array}$ & $\begin{array}{ll}\text { - } & \text { Pembuatan sari bunga } \\
& \text { telang } \\
\text { - } & \text { Pembuatan cendol pati } \\
\text { - } & \text { Pembagian Kuisioner }\end{array}$ & Ibu-ibu PKK dan karang taruna \\
\hline
\end{tabular}




\section{Bentuk kegiatan}

Setiap tahapan pelaksanaan pengabdian masyarakat dengan menggunakan prinsip bahwa setiap inovasi yang diterima oleh mitra sebaiknya melalui proses mendengar, mengetahui, mencoba, mengevaluasi, menerima, dan melaksanakan. Melalui proses-proses tersebut diharapkan inovasi dapat diadopsi secara berkesinambungan, serta target sasaran mempunyai kemampuan untuk mampu mengembangkan inovasi yang telah dikuasainya. Supaya setiap proses berlangsung dengan baik, maka penyampaian inovasi kepada mitra ditempuh melalui tahapan penjelasan, diskusi, dan praktek langsung serta dilakukan tahapan pendampingan. Adapun metode pelaksanaan yang digunakan yaitu tahap perencanaan, pelaksanaan, evaluasi, dan pendampingan budidaya bunga telang. Tahap perencanaan meliputi observasi dan perizinan.

\section{Tahap perencanaan}

a. Observasi

Observasi dilakukan untuk melihat sumberdaya bunga telang yang terdapat di desa Datengan supaya pada waktu pelaksanaan pengabdian dapat berjalan lancar.

\section{b. Perizinan}

Melakukan perizinan dan sosialisasi pada pihak-pihak terkait antara lain Kepala Desa Datengan sebagai mitra langsung, ibu-ibu PKK yang berada di Desa Datengan, kelompok tani dan karang taruna serta dinas terkait seperti Kecamatan Grogol, Dinas Pertanian dan Perkebunan Kabupaten Kediri dan Pemerintah Kabupaten Kediri.

\section{Tahap Pendidikan dan Pelatihan}

Tahap pendidikan dan pelatihan (diklat) yang dilakukan yaitu penyuluhan mengenai manfaat bunga telang sebagai pewarna alami warna biru dan pelatihan pembuatan cendol pati dengan pewarna alami. Setelah tahap pendidikan dan pelatihan ini masyarakat dapat menggunakan kemampuannya untuk menggunakan pewarna alami bunga telang pada pembuatan cendol pati.

\section{Evaluasi Kegiatan}

Evaluasi merupakan satu tahapan yang terpenting dari kegiatan pengabdian masyarakat. Tahap evaluasi dilaksanakan dengan tujuan yaitu a) melihat seberapa jauh pengetahuan mitra mengenai realisasi antara teori dalam pelatihan dan praktik yang telah dilakukan, b) evaluasi hasil pembuatan cendol dengan pewarna alami.

Tahap evaluasi merupakan hal penting selama pelaksanaan kegiatan yang berfokus pada penyampaian materi dan praktek. Pada tahap ini, peserta diberikan kesempatan untuk bertanya tentang materi yang telah disampaikan oleh pemateri selama proses pelatihan dan pelatihan pembuatan cendol pati dengan pewarna alami biru dari sari bunga telang. Pemahaman terhadap materi yang telah disampaikan dan ketrampilan yang telah dipraktekkan merupakan indikator dari keberhasilan pelatihan. Kriteria keberhasilan pelaksanaan kegiatan sebagai berikut: a) $80 \%$ peserta mampu menjawab dengan benar pertanyaan yang diberikan setelah kegiatan pelatihan, b) $80 \%$ peserta mendapatkan keahlian teknik dan mampu mempraktekkan pembuatan pewarna alami biru dari bunga telang, dan c) $80 \%$ peserta dapat menciptakan variasi olahan bunga telang berupa cendol pati warna biru yang dapat digunakan untuk menunjang perekonomian kreatif masyarakat Desa Datengan Kecamatn Grogol Kabupaten Kediri.

Parameter keberhasilan kegiatan pengabdian ini adalah meningkatnya pengetahuan mitra mengenai pemanfaatan sari bunga telang sebagai pewarna alami warna biru pada pembuatan cendol pati. Evaluasi kegiatan ini dilaksanakan dengan memberikan kuisioner diawal (pretest) dan diakhir (posttest) penyuluhan. Kuisioner yang diberikan berisi pertanyaan-pertanyaan terkait materi yang disampaikan pada penyuluhan. Jika skor posttest peserta yang dihasilkan lebih baik daripada pretest, maka hal tersebut mengindikasikan jika penyuluhan ini telah berhasil (Sariwati et al., 2019; Shofi, 2019).

\section{HASIL DAN PEMBAHASAN}

\section{Tahap persiapan}

Tahap persiapan pada pelaksanaan kegiatan pengabdian masyarakat di Dusun Datengan Desa Datengan Kecamatan Grogol Kabupaten Kediri yaitu tahap perizinan dan sosialisasi kegiatan dilakukan dua minggu sebelum pelaksanaan pelatihan dan pendampingan. Perizinan dan sosialisasi dilakukan secara lisan dan langsung menemui Kepala Desa Datengan. Pada kegiatan sosialisasi ini dilakukan penyampaian gambaran umum kegiatan, tujuan, dan diskusi dengan Kepala Desa sehingga diperoleh ijin untuk melaksanakan kegiatan pengabdian masyarakat di wilayah kerjanya. Persiapan pelaksanaan kegiatan ini dihadiri oleh tim pengusul dan kepala desa beserta perangkat desa serta mahasiswa yang akan terlibat pada kegiatan pengabdian masyarakat. 


\section{Kegiatan penyuluhan}

Kelompok sasaran pelatihan ini adalah warga Dusun Datengan Desa Datengan Kecamatan Grogol Kabupaten Kediri dengan jumlah peserta pengabdian sebanyak 63 orang (Lampiran 1). Berdasarkan hasil wawancara pada peserta, belum banyak mengetahu manfaat dari bunga telang terutama sebagai pewarna alami warna biru. Adanya hal tersebut perlu adanya pelatihan pembuatan pewarna alami warna biru menggunakan sari bunga telang.

Tahap selanjutnya adalah tahapan sosialisasi dan persiapan kegiatan pelatihan dan pendampingan terhadap mitra pengabdian yaitu warga Desa Datengan. Pada tahap ini tim berkunjung kepada mitra untuk mensosialisasikan kegiatan pelatihan dan pendampingan, menjelaskan peran mitra dalam kegiatan. Adapun sosialisasi yang dilakukan terhadap mitra adalah rencana pelatihan pembuatan pewarna alami warna biru dari bunga telang sebagai pewarna makanan yang sehat dan kaya akan antioksidan. Selain sosialisasi mengenai kegiatan pelatihan dan pendampingan, sosialisasi juga membahas tentang kesiapan mitra dalam pelaksanaan pelatihan dan pendampingan, tempat pelaksanaan pelatihan dan pendampingan, dan kesiapan anggota kelompok dalam melaksanakan pelatihan dan pendampingan. Saat sosialisasi tidak ditemui kendala yang berarti karena masyarakat mengharapkan adanya kegiatan pelatihan dan pendampingan yang dilaksanakan di Desa Datengan. Dampak dengan adanya sosialisasi ini adalah mitra menjadi mengerti tujuan adanya program pelatihan dan pendampingan yang dilakukan, mitra menjadi paham tupoksi sebelum dilaksanakan kegiatan pelatihan dan pendampingan. Harapan dari tim pelaksana dengan adanya pelatihan pembuatan pewarna alami warna biru dari bunga telang sebagai pewarna makanan yang sehat dan kaya akan antioksidan dapat meningkatkan pengetahuan tentang manfaat bunga telang yang selama ini belum banyak diketahui oleh masyarakat.

Tahap berikutnya itu pelatihan dan pendampingan kepada mitra pengabdian. Tahap ini bertujuan untuk meningkatkan pengetahuan dan keterampilan peserta tentang bagaimana pembuatan pewarna alami warna biru dari bunga telang sebagai pewarna makanan yang sehat dan kaya akan antioksidan. Sebelum penyampaian materi dilakukan pretest terlebih dahulu untuk mengetahui tingkat pengetahuan peserta tentang pembuatan pewarna alami warna biru dari bunga telang sebagai pewarna makanan yang sehat dan kaya akan antioksidan. Berdasarkan pada Gambar 3 menunjukkan bahwa tingkat pengetahuan mitra mengenai manfaat bunga telang sebagai pewarna alami masih rendah, hal tersebut terbukti dari hasil pretest menunjukan hampir $80 \%$ tidak mengetahui tentang hal tersebut.

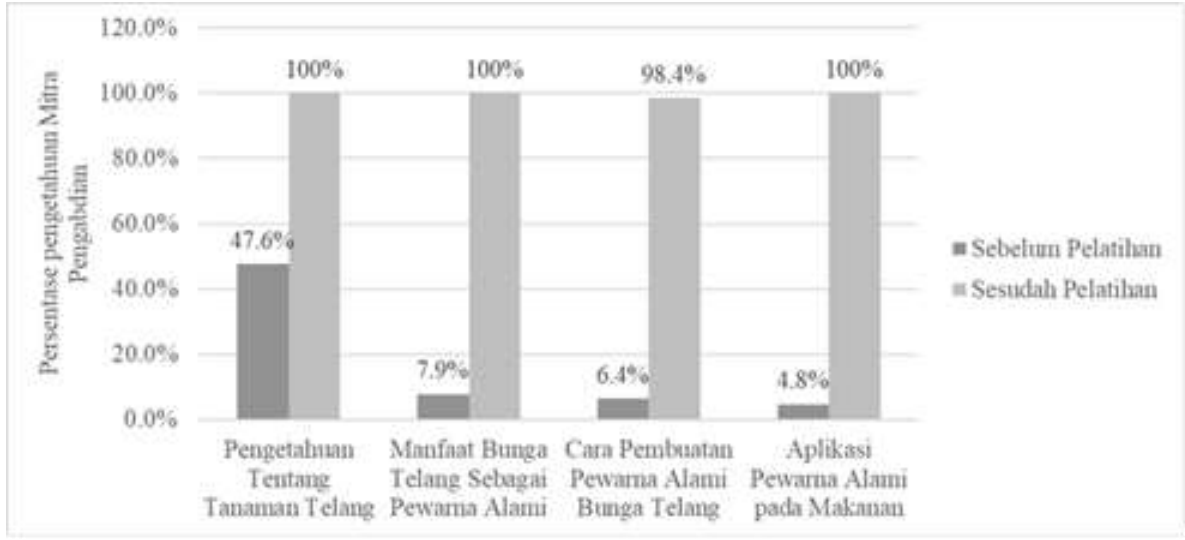

Gambar 3. Persentase tingkat pengetahuan peserta sebelum dan setelah pengabdian masyarakat

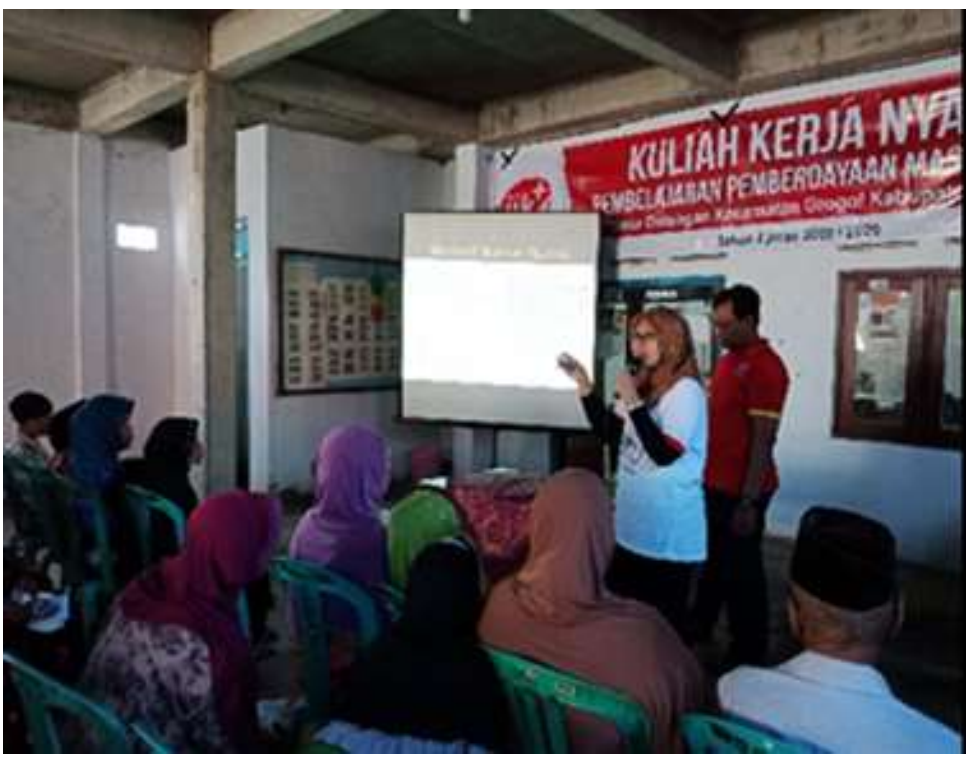

Gambar 4. Penyampaian materi oleh tim pengabdian 
Setelah diadakan pretest kemudian dilanjutkan dengan sosialisasi tentang bunga telang dan manfaatnya sebagai pewarna alami (Gambar 4). Penyampaian materi dilakukan dengan ceramah menggunakan media powerpoint dengan 4 pokok bahasan, yaitu (a) Pengenalan tanaman telang; (b) Manfaat bunga telang sebagai pewarna alami warna biru; (c) Cara pembuatan pewarna alami dari sari bunga telang; dan (d) Aplikasi pewarna alami sari bunga telang pada makanan

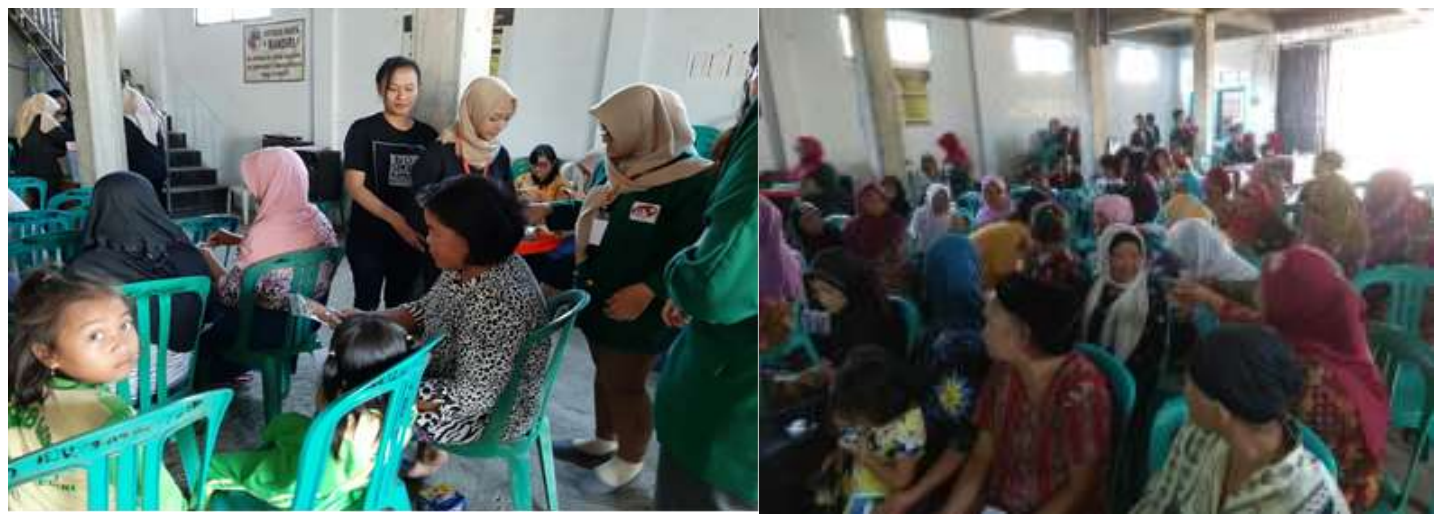

Gambar 5. Antusias mitra mendengarkan materi tentang pemanfaatan bunga telang sebagai pewarana alami warna biru

Berdasarkan hasil pengamatan pada saat pemberian materi, peserta terlihat antusias pada materi yang disampaikan (Gambar 5). Hal tersebut terbukti banyak peserta menanyakan tentang manfaat bunga telang sebagai pewarna alami.

Setelah penyampaian materi oleh tim pengabdian, peserta langsung mempraktekkan cara pembuatan cendol pati dengan pewarna alami dari sari bunga telang. Peserta dibimbing dengan beberapa mahasiswa untuk langkah langkah pembuatan sari bunga telang dan pembuatan cendol.

Berdasarkan hasil kuisioner setelah kegiatan berlangsung, terdapat peningkatan pengetahuan mitra pengabdian masyarakat yang sangat signifikan. Terlihat pada Gambar 3 responden menyatakan semuanya mengetahui tentang pembuatan sari bunga telang dan pembuatan cendol dengan penambahan warna biru dari sari bunga telang. Hal ini terbukti dengan hasil kuisioner 100\% menjawab "ya". Berdasarkan hasil tersebut, dapat dinyatakan bahwa pelatihan pembuatan pewarna alami dari bunga telang sebagai pewarna pada pembuatan cendol pati berhasil meningkatkan pengetahuan mitra tentang pemanfaatan bunga telang sebagai pewarna alami.

Setelah dilakukan pelatihan ini, selanjutnya adalah tahap evaluasi kegiatan. Evaluasi suatu kegiatan diperlukan untuk mengetahui sejauh mana kesesuaian program didesain, apakah sesuai dengan tujuan yang dimaksud, apakah menjangkau populasi yang dimaksud, dan apakah efektif dalam mencapai tujuan yang dimaksud (Purwandhani et al., 2019). Adapun cara evaluasinya yaitu dengan membandingkan pengetahuan dan pemahaman peserta sebelum dan sesudah pemberian pelatihan. Secara umum menunjukkan terjadi peningkatan pengetahuan peserta, dimana ditunjukkan pada saat praktik semua bisa melakukan dengan mandiri, dan mampu menjelaskan kembali saat diberi pertanyaan dalam sesi praktek langsung. Berdasarkan hasil kuisinoner, terdapat peningkatan pengetahuan mitra pengabdian masyarakat sebesar $100 \%$ jika dibandingkan sebelum dilakukan pelatihan (Gambar 4). Tabel 2 berikut ini menunjukkan kriteria dan indikator keberhasilan kegiatan pengabdian masyarakat ini.

Tabel 2. Indikator keberhasilan kegiatan

\begin{tabular}{ll}
\hline \multicolumn{1}{c}{ Kriteria } & \multicolumn{1}{c}{ Indikator } \\
\hline Tingkat partisipasi & $\begin{array}{l}\text { Kegiatan pelatihan sangat diminati oleh masyarakat mitra sebab dari undangan yang disebar } 61 \text { orang yang } \\
\text { hadir. }\end{array}$ \\
\hline $\begin{array}{l}\text { Tingkat pemahaman } \\
\text { terhadap materi pelatihan }\end{array}$ & $\begin{array}{l}\text { Tercermin terjadi proses peningkatan pemahaman tentang pemanfaatan bunga telang sebagai pewarna } \\
\text { alami warna biru. Peserta sangat aktif dalam diskusi, tanya jawab, menyampikan ide dan mampu } \\
\text { mempraktikkan dengan baik. Peserta sangat serius dan antusias mengikuti dari awal hingga selesai acara }\end{array}$ \\
\hline Kesesuaian materi & Peserta mampu mempraktikkan teknik pembuatan sari bunga telang dan aplikasinya pada pemberian warna \\
& pada pembuatan cendol pati \\
\hline & Menurut pendapat peserta, materi pelatihan sangat menarik. Cara penyampaian yang baik dan komunikatif \\
& sehingga memudahkan dan menarik peserta untuk mengikuti dan memahami materi tentang pemanfaatan \\
& bunga telang sebagai pewarna alami warna biru pada pembuatan cendol pati
\end{tabular}

Secara umum kegiatan pengabdian ini berhasil jika dilihat dari beberapa indikator yang terdapat pada Tabel 2. Ada beberapa faktor yang menjadi pendorong keberhasilan acara ini, yaitu bahwa kegiatan ini dirancang dengan keterlibatan yang tinggi dari mitra pengabdian. Permasalahan yang diangkat dan diidentifikasi diperoleh secara langsung sehingga mitra pengabdian masyarakat sangat antusias ketika mengikuti setiap tahap pengabdian masyarakat. Narasumber yang memberikan pelatihan sangat komunikatif yang sangat baik sehingga bisa menyatu dengan peserta baik secara formal maupun informal. Selain itu dapat dapat menaikkan nilai ekonomis dari bunga telang yang selama ini kurang dipahami oleh masyarakat mitra pengabdian. Faktor yang menjadi penghambat yaitu masih kurangnya sumberdaya bunga telang 
sehingga hanya sebagain peserta saja yang mempraktekkan pembuatan sari bunga telang sebagai pewarna biru alami pada pembuatan cendol pati.

\section{KESIMPULAN}

Kesimpulan dari kegiatan pengabdian ini adalah bahwa dengan metode yang digunakan pada kegiatan ini telah mampu meningkatkan pengetahuan mitra yaitu warga Dusun Datengan Desa Datengan Kecamatan Grogol Kabupaten Kediri terkait pengetahuan tentang pemanfaatan bunga telang sebagai pewarna alami warna biru sebagai pewarna pembuatan cendol pati. Hal tersebut dapat dilihat dari peningkatan persentase pengetahuan yang rata-rata sebelum kegiatan sebesar $10 \%$ menjadi sebesar $100 \%$.

\section{REFERENSI}

Ana, Z., Laurent, B. K., \& Budiyati, C. S. (2012). Ekstraksi dan analisis zat warna biru (anthosianin) dari bunga telang (Clitoria ternatea) sebagai pewarna alami. Jurnal Teknologi Kimia dan Industri, 1(1), 356-365. Retrieved from https://ejournal3.undip.ac.id/index.php/jtki/article/view/949

BPS. (2018). Kecamatan Grogol dalam angka tahun 2018. Badan Pusat Statistik Kabupaten Kediri.

Purwandhani, S. N., Kusumastuti, C. T., \& Indroprahasto, S. (2019). Program kemitraan masyarakat bagi kelompok wanita tani Ngupoyo Boga Godean, Sleman, Yogyakarta dalam pengolahan bunga telang. In SENADIMAS UNISRI (hal. 83-89). Retrieved from https://docplayer.info/amp/182094267-Program-kemitraan-masyarakat-bagikelompok-wanita-tani-ngupoyo-boga-godean-sleman-yogyakarta-dalam-pengolahan-bunga-telang.html

Sariwati, A. Shofi, M., Badriyah, L. 2019. Pelatihan pemanfaatan limbah botol plastik sebagai media pertumbuhan tanaman hidroponik. Journal of Community Enggagement and Empowerment 1(1) : 6-13. Retrieved from https://ojs.iik.ac.id/index.php/JCEE/article/view/278

Shofi, M. 2019. Pemberdayaan anggota PKK melalui pembuatan lilin aromaterapi. Journal of Community Enggagement and Empowerment 1(1), 40-46. Retrieved from https://ojs.iik.ac.id/index.php/JCEE/article/view/283

Shyamkumar, I. B., \& Ishwar, B. (2012). Anti-inflammatory, analgesic, and phytochemical studies of Clitoria ternatea Linn flower extract. International Research Journal of pharmacy, 3(3), 208-210. Retreived from https://irjponline.com/details.php?article=935

Uma, B., Prabhakar, K., \& Rajendran, S. (2009). Phytochemical analysis and antimicrobial activity of Clitorea ternatea Linn against extended spectrum beta lactamase producing enteric and urinary pathogens. Asian Journal of Pharmaceutical and Clinical Research, 2(4), 94-96. Retrieved from https://innovareacademics.in/journal/ajpcr/Vol2lssue4/228.pdf

Vankar, P. S., \& Srivastava, J. (2010). Evaluation of anthocyanin content in red and blue flowers. International Journal of Food Engineering, 6(4), 1-11. https://doi.org/10.2202/1556-3758.1907 